\title{
Enhancing police integrity by exploring causes of police corruption
}

\author{
Shakeel Ahmad Khan ${ }^{a^{*}}$, Alia Ahmed ${ }^{a}$ and Kaleem Ahmed
}

${ }^{a}$ National college of business administration and economics Lahore, Pakistan ${ }^{b}$ University of Lahore, Gujrat campus, Pakistan

C H R O N I C L E

\section{Article history:}

Received: November 18, 2020

Received in revised format:

December 282020

Accepted: December 29, 2020

Available online:

December 29, 2020

Keywords:

Bribery

Social

Economic

Pakistan

Corruption

\section{A B S T R A C T}

Methods for the elimination of police corruption to enhance integrity, usually disregards its roots that are connected to societal elements in light of the fact that police corruption has societal causes and implementing a change of the police needs, to certain degree, transforming the community. In this research, a qualitative approach (semi-structured interviews, focus group meetings and observations) was used the analysis methods from social profiles categorized as per their degree of police corruption utilizing data. Researchers have described and examined the organizational and social determinants of police corruption to help decision-makers establish social and economic policy frameworks to monitor police corruption. Researchers concluded that poor pay, resource shortage, moral economy, and politicization of police are pertinent to police corruption. In addition, research evidence suggests that the government must increasingly strengthen organizational as well as social measures in order to minimize police corruption.

\section{Introduction}

The major outbreak of the world is corruption. It is nevertheless prevalent and still a structural issue that is entrenched in all social and governmental stages in Pakistan (Dogar, 2017). And as per the recent official figures, corruption in public sector corporations was Rs 852 billion (USD 8,192,307,692) only in 2016 (Sajid, 2016). Pakistan is ranked 117 th out of 180 corrupt countries in the Transparency International (TI) Corruption Perception Index (CPI) (TI, 2019). Although the CPI warns policymakers regarding corruption, "it is not enough to indicate the corruption rate in underdeveloped nations as the corruption understanding does not always represent the fact or severity of a country's current level of corruption" (Madichie, 2005, p. 320; Quah, 2006, 2010). This is significant for Pakistan, in which corruption has become a social way of life and an examination of perceptions of corruption does not clarify a complete understanding. Corruption within the police department is of critical challenge for all government officials while Pakistan is a scenario where there has been a substantial erosion of the legal system in terms of religious intolerance, sectarian, ethnical and gender violence and rising misery, injustice and crime. Law and government deterioration also have significant implications for economic development and foreign investments in the nation (Raza et al., 2015). Due to various unethical activities, the police cannot meet these problems (TI, 2013). The comprehensive essence of police corruption and the reasons of it in Pakistan must somehow be understood (Babakhel, 2018).

\subsection{Problem Statement}

There is a lack of research on the corruption of police in Pakistan considering the seriousness of the problem. One explanation is that in the state the study of criminology is hardly examined. Of the 133 colleges, only three provide their graduates criminology (Fasihuddin, 2013). Excluding Jackson et al. (2014), little police studies have focused on other facets of policing, such

* Corresponding author.

E-mail address: khnshakeel@yahoo.com (S. A. Khan) 
as policing performance reforms, lack of preparation, insufficient wages, lack of accounting, lack of strong criteria and lack of police credibility (see Chattha \& Ivkovic, 2004; Abbas, 2011; Ahmed \& Ahmed, 2012). These researches indicated higher pay, better preparation and curricula, increased community understanding, evolving corporate culture, the availability of new forensic technologies, and police accountability reform for the criminal justice system.

Nevertheless, Jackson et al. (2014) explored the theoretical relations that exist between the understanding of police corruption by individuals and the understanding of equity and efficiency and their assumptions regarding police legitimacy. Their results show that police credibility can depend not only on the judicial discretion of officers but also on their proven capacity to monitor violence and prevent corruption, in Pakistan's background when minimum effectiveness and honesty are to be developed though (Jackson et al., 2014, p. 2; Zakiuddin \& Haque, 1998). However, the major objective of the investigations is on police credibility and the reasons of police corruption are not properly examined.

\subsection{Research gap}

This research fills the gap by reflecting on many sources of corruption in police forces. The problem of police corruption in Pakistan is complicated, and in one study its numerous configurations and features cannot be fully explained. This study though goes beyond examination of police reforms, policing processes and accounting or efforts to eliminate corruption in the police. Thus, it is beyond this context. The study focuses on the economic, cultural and policy reasons that have arisen out of our fieldwork in Pakistan of police corruption.

Police corruption in Pakistan has been illustrated to be politicized, institutionalized and legitimized. Thus, it is important that several triggers, which are of wider relevance to many other South Emerging markets, of police corruption in Pakistan be examined (Kleinig, 1996).

\subsection{Research aims}

In order to define policymakers with the core values for designing a long-term anti-corrosion plan aimed at improving the social climate, this study defines the organizational and social factors involved in police corruption.

\subsection{Research questions}

Q: What are the organizational and societal causes of police corruption, identified by qualitative analysis, that can halt the process of police integrity?

\subsection{Contribution of the study}

The main aim of this research is that we suggest a range of core values through qualitative analysis that enable policy makers to establish societal policies to track policing corruption through the improvement of social measures. Researchers further contribute to the list of social causes of police corruption by evaluating relevant methods. In addition, we include research evidence that show that nations steadily develop social metrics to mitigate police corruption.

\section{Literature review}

\subsection{Police misconduct and police corruption}

Police misconduct is a broad concept that encompasses a heterogeneous set of behaviours, from sleeping on duty, being late for work, and using excessive force, to denying the 5th Amendment right to silence, testifying, forging documents, and accepting bribes. Traditionally, these diverge activities are classified as corruption, use of excessive force, and other forms of police misconduct or police deviance. Barker (2002) uses a somewhat different classification; he groups what he calls ethical violations into organizational/rule violations, money corruption, and abuse of authority."

Perez and Moore "(2002, pp. 132-5) employ another classification and list five distinct categories of police misconduct: corruption of authority, noble cause corruption, police crime, ineptitude, and personal misbehaviour. Regardless of the specific classification, corruption is distinguished from other forms of police misconduct based of its primary motivation: achievement of personal gain. This notion has not escaped policing scholars; the element of personal gain is typically an integral part of the definition. For example, Goldstein (1975, p. 3, emphasis added), the grandfather of the problem-solving approach to policing, views corruption ... as acts involving the misuse of authority by a police officer in a manner designed to produce personal gain ..." [emphasis added].

"Definitions of police corruption typically disagree on whether use of excessive force and criminal activities such as robberies or burglaries should be covered by the definition. One of the frequently used typologies of corruption by Barker and Roebuck (1973) provides a rather broad understanding of what corruption is. Barker and Roebuck (1973, p. 21) classify diverse types of police corruption according to five dimensions (act and actors involved, nature of norms violated, degree of peer group 
support, required degree of deviant organization, and departmental reaction)." They differentiate among eight corruption types:

\subsubsection{Corruption of authority}

The officer's authority is corrupted when he receives officially unauthorized, unearned material gain by virtue of his position as a police officer without violating the law per se (Barker \& Roebuck, 1973, p. 21). This category is very broad; the authors provide examples ranging from the acceptance of free drinks, free food, discounts on merchandise, to providing property protection for a fee.

\subsubsection{Kickbacks}

The acceptance of goods, services, or money for referring business to various businesses and service providers, including towing companies, ambulances, garages, lawyers, doctors, etc. (Barker \& Roebuck, 1973, p. 24).

\subsubsection{Shakedowns}

They occur upon the police officer's discovery of the criminal violation and the violator, and result in the police officer's acceptance of a bribe in order not to make an arrest" (Barker and Roebuck, 1973, p. 27).

\subsubsection{Protection of illegal activities}

Individuals involved in illegal activities provide services and goods to the citizens and reward police officers in order to operate without police harassment" (Barker \& Roebuck, 1973, p. 31).

\subsubsection{The fix}

A police officer fixes the case in exchange for a gain. Instances of the fix may include the quashing of prosecution proceedings following the offender's arrest and ...the taking up (disposal of record) of traffic tickets" (Barker \& Roebuck, 1973, p. 34).

\subsubsection{Opportunistic Theft}

Theft of property from arrestees, victims, and crime scenes, and theft of unprotected property (Barker and Roebuck, 1973, p. 26). These thefts may be classified as police corruption because they satisfy the necessary condition - the misuse of the police officers' authority: they are facilitated by the opportunities provided through their police occupation (Bardhan, 1997).

\subsubsection{Direct criminal activities}

Policemen directly commit crimes against the person or property of another for material gain, acts which are a clear violation of both departmental and criminal norms" (Barker \& Roebuck, 1973, pp. 35-6; Gupta, 1995; Waddington, 1999).

\subsubsection{Internal payoffs}

Both the corruptors and the corrupt are police officers, who sell or buy assignments, off-days, holidays, promotions, etc" (Barker \& Roebuck, 1973, p. 36; Dias \& Vaughn, 2006; Hurbert, 2002; Jancsics, 2014; Klitgaard, 1988).

"While the classification of corruption indeed remains stable over time, the frequency with which specific forms are represented and their specific nature do tend to evolve. Contemporary corruption, as documented by the Mollen Commission investigating corruption in New York in the $1990 \mathrm{~s}$, tends to be more violent and premeditated in nature than traditional police corruption was two decades ago" (Mollen Commission, 1994, Exhibit 6, p. 4; Heywood, 1997; Verma, 1999):

"While the systematic and institutionalized bribery schemes that plagued the Department a generation ago no longer exist, the prevalent forms of police corruption today exhibit an even more invidious and violent character: police officers assisting and profiting from drug traffickers, committing larceny, burglary, and robbery, conducting warrantless searches and seizures, committing perjury and falsifying statements, and brutally assaulting citizens. This corruption is characterized by abuse and extortion, rather than by accommodation - principally through bribery - typical of traditional police corruption."

\subsection{Measuring crime severity}

The topic of crime severity was spurred by the seminal study by Sellin and Wolfgang (1964). The respondents, ranging from college students to police officers, were asked to evaluate the seriousness of vignettes describing criminal behavior. Sellin and Wolfgang (1964, p. 268) reported that, while the respondents' evaluations of case seriousness (i.e. absolute seriousness) differed greatly across individual respondents and groups of respondents, the ranking of a case in terms of its seriousness compared to the other cases (i.e. relative seriousness) was rather stable and was shared across the groups. Sellin and Wolfgang (1964, p. 275) thus argued that relative seriousness is of greater importance than absolute seriousness:" 
“... although absolute numerical scores varied among rating groups, with the police scores generally higher, the inherent ratio quality of the magnitude judgments means that the numbers used by the ratters are not particularly relevant and that the only fact of real importance is the ratios of offense seriousness which are preserved intact."

"Subsequent research yielded consistent results: despite the differences in the absolute values between various groups - offenders and non-offenders (Velez-Diaz and Megargee, 1971; Figlio, 1975), men and women (Rossi et al., 1985), AfricanAmerican respondents and Caucasian respondents (Rossi et al., 1985; Wolfgang et al., 1985), the old and the young (Wolfgang et al., 1985), and victims and non-victims (Wolfgang et al.,1985) - there is a high degree of similarity in terms of relative seriousness" (Velez-Diaz and Megargee, 1971; Figlio, 1975; Rossi et al., 1985; Wolfgang et al., 1985).

\subsection{Seriousness of police corruption}

While there is extensive prior literature on crime severity or crime seriousness, starting from Sellin and Wolfgang's pioneering study in 1964, a common feature is that vignettes describing police corruption had rarely been included in these studies. Typically, if corrupt behavior is incorporated in the instrument, the vignette describes the basic quid-pro-quo corruption. Wolfgang et al. (1985) used a case in which a police officer accepted a bribe in exchange for not interfering with an illegal gambling operation. Respondents evaluated such behavior as much less serious than the acceptance of a bribe by a county judge in exchange for a lighter sentence and as somewhat less serious than the acceptance of a bribe by a legislator in exchange for voting for a law favoring a company."

"Because a typical quid pro quo corrupt transaction has two sides - the bribe taker (police officer, judge, and legislator) and the bribe giver (public official, citizen, and company) - the researchers examined whether the behavior by the two sides carries the same weight. The results of the studies (Rossi et al., 1974; Wolfgang et al., 1985; Rebovich and Layne, 2000) unequivocally suggest that the acceptance of a bribe by a public official is viewed as more serious than the offering of a bribe by a citizen. This discrepancy between the evaluations of seriousness of bribe taking by a public official and bribe giving by a citizen/company persists even when the amount of the bribe accepted is ten times lower than the amount of the bribe offered" (Wolfgang et al., 1985; Kaufmann \& Vicente, 2011; Lee et al., 2013).

"A series of research projects focused exclusively on police misconduct. Using mostly the same set of hypothetical cases that describes various forms of police misconduct, Martin (1994) and Knowles (1996) find that police officers in Illinois and Ohio perceived acceptance of a bribe, theft of property, planting of a weapon on a suspect, and drug use as the most serious forms of misconduct (Martin, 1994, p. 23; Gregory, 1999). On the other hand, respondents classified racial profiling, flashing a badge to avoid a traffic citation, and speeding when there is no emergency as the least serious behaviors (Martin, 1994, p. 24). The Australian Criminal Justice Commission (1999) reports similar results. In particular, the least serious cases involved acceptance of holiday gifts, pick-up of personal equipment outside of the patrol area, and punching an arrested suspect being led into the cells, while the most serious cases involved falsification of official records (e.g. adding words to the suspected rapist's statement), stealing items of small value from the crime scene and stealing and selling confiscated drugs.

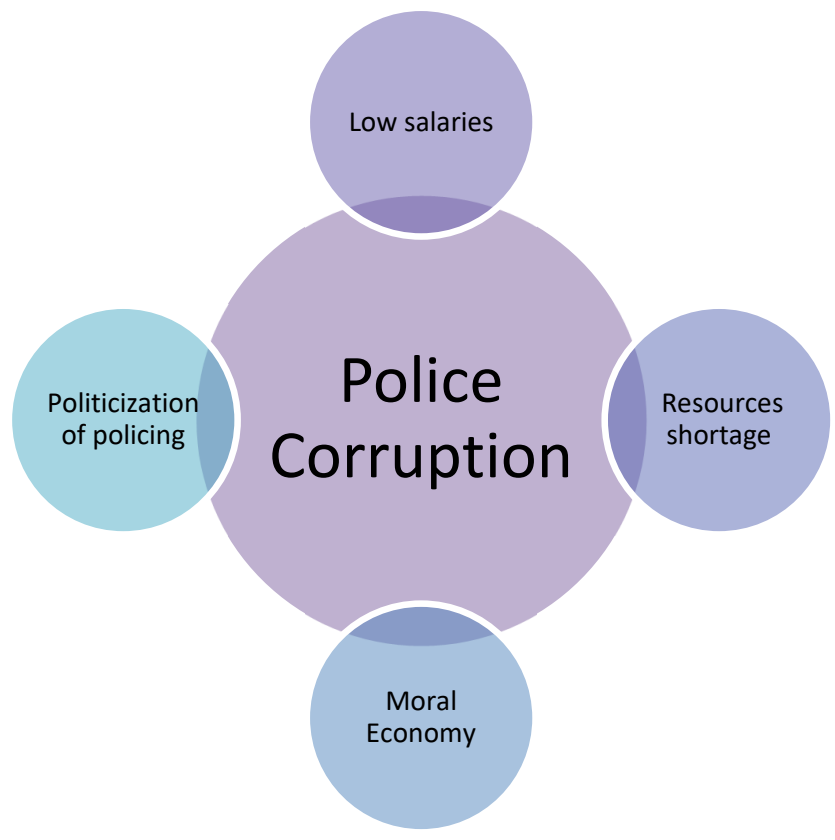

Theoretical model 


\section{Research methodology}

The analysis is qualitative. The analysis was carried out between September 2020 and January 2021. Even so, as part of its Doctoral degree at National College of business administration and economics in 2018, the co-author conducted a preliminary analysis. This study builds on certain original thoughts in the earlier findings. Semi-structured interviews, focus group meetings and observations were used the analysis methods. The research follows a paradigm of interpretive research. In contrasts with statistical methods used in the positivist study, the interpretative paradigm focuses on the meanings from a participant's viewpoint (Graaf, 2007; Noon, 2018).

\subsection{Population of sample study}

The research employed a purposive sampling method to ensure the respondents chosen were ideally suited to the research of police corruption. Without proper screening of individuals, data processing could be challenging and time-consuming. The method of calculating permissions has been used to exclude unnecessary respondents (Fluid Survey, 2013). The key attributes evaluated were whether respondents had some skills (e.g. considerable expertise in the field of work) that rendered them eligible to research or had in-depth background or expertise of police corruption. Initially there were already connections and the techniques of snowball. The strategy of snowball is compatible with purposive sampling when a Group of individuals proposes possible research participants (Buttle et al., 2016; Naderifar et al., 2017; Naderifar et al., 2017).

We aggregated the data after Chadwick et al. (1984). Data collecting from multiple sources requires triangulation using different techniques. Academic books and papers, newspaper articles, government records, and primary information have been obtained from secondary sources by police ( 8 senior officers (Deputy Police Superintendents (DPs)), Deputy Police Inspector General (DIGs), six midlevel officers (i.e. SHOs), investigative officers and the site. Additional police members including policy experts (Seven), criminal advocates (Seven), and community officials involved (48 in 6 Focus Group meetings (8 respondents per Focus Group)). The researchers agreed after an interview with 82 participants that this study achieved concentration. 10-25 interviews to reach saturation are commonly advised (Creswell, 2013). The quotation form of statements adopted by respondents corresponds to the police analysis of Reynolds et al. (2018). In other words, we adopted the commentary style used by Reynolds et al.

\subsection{Data collection tools and techniques}

Although there's no administrative research agency in Pakistan, the researchers have discussed the obligation of study in accordance with the Australian Code (2018). For the purpose of illustrating study objectives and what was expected of respondents through interviews and focus meetings, participants were presented with the clear language statement for their approval. The written consent of all respondents to engage was confirmed. All interviews were written and recorded descriptively. The documents were subsequently coded to secure respondents' information. The identities of the individuals concerned are not indicated in terms of privacy and confidentiality, and the police stations in which they are situated and the towns, villages or districts in which they are situated. In addition, the positions of the respondents are not stated in the study that proceeds, to maintain privacy and confidentiality. In computer records that are password-protected, the data is maintained for 5 years under the Australian Code on Responsible Research (2007). After the interviews were finished, transcripts were created in order to ensure continuity and contrasted with audio tapes. At the point of data processing, the data collected is thematically classified. The established categories were contrasted and the associations were analyzed. Personal statements, suggestions or memoranda have been made during this process. These notes helped to focus on the study results and address them (Porter \& Warrender, 2009; Punch, 2005, 2009, 2010; Sissener, 2001; Tankebe, 2010; Uberti, 2016).

\section{Findings}

This section analyses four main variables of police corruption in Pakistan, i.e. (1) low salary, (2) resources shortage, (3) the politicization of the police, and (4) moral economy." Khan (2006) concluded that in developed nations policy consolidation is usually accomplished by straightforward monetary adjustment, while policy stabilization in underdeveloped nations entails political corruption in connection with instability. At economic level, higher tax revenue in developed nations means that the type of clear tax transfers will contribute to political stabilization. Around the same time the manufacturing sector creates a sufficient surplus to pay taxes to defend property rights efficiently, minimizing the risk of expropriation. In underdeveloped nations, however, the economic output is poor, and resource allocation is not clear. The tax system in Pakistan is regressive, with the poor paying more taxes, which further raise poverty. The utilization of funds is not clear, and political leaders tend to invest more on initiatives of greater exposure and aesthetics, than on expenditure on protection and growth for people. As a result, low pay rates are charged to police officials and inadequate resources are required for police operations. Both lead to corruption in the police. Below you can find an outline of both.

\subsection{Low salaries}

In Rose-Ackerman (1999, p. 72), the police force participates in corrupt operations for stability in nations where police officers are not supported with sufficient pay. Researcher observation matches well with Pakistan's situation. There are many rewards 
for corruption in a country in which four of ten Pakistanis live in multidimensional poverty (UNDP, 2016). The policeman's authority is abundant. Corruption is not at risk unless the whole system is corrupt (Khan et al., 2012). The policemen's pay package is in stark contrast to their duties. The monthly salaries of a policeman's policeman are about 83 dollars, the head officer 89 dollars, the sub-inspector 107 dollars, the police inspector 122, and SP 288 dollars, the police DIG 576 dollars, and the inspector General \$ 577 dollars (GoP, 2017-2018). Few officers have additional allowances for their particular duties, however the picture overall is not distinct from that seen above. The average outgoings are incredibly high, that is to say. RP 119,927.81 (Monthly US\$776726) (Transfer Wise, 2017; Rijckeghem \& Weder, 2001; Shore \& Haller, 2005). Also, senior police officers find it difficult to achieve both purposes. There are very few administration residences for the low-ranking officials, according to all the police officers. In major urban centers, high-ranking police officers frequently do not have housing. Because the government does not have 'insurance coverage,' the police must carry on their limited salary package the expense of healthcare' (Senior officer 1). The annual inflation rate is twofold and 'the rise in wages after five to seven years besides annual raises is declared' (Senior officer 2). Junior officers ( 90 percent) denied that no structured holiday plan exists and spends hours without end. You accused your senior colleagues of not giving them space to relax and maintain a balance between business and pleasure. The police officers 'shall be on service for 16-18 hours, 7 days a week with no additional pay and no daily duty lists are in place' (Junior officer 3). Long hours of work and low pay induce severe anxiety and burnout amongst these officers (Junior officer 4). The other 10 percent junior officers found the absence of sufficient police officers to be a leading cause. All senior and medium-sized police officials have shared this opinion. The shortage of salaries thus impairs job efficiency, competitiveness and moral characteristics. Analysts predict that poor salaries adversely affect workers' morals and efficiency (Paul and Du, 2018). When long hours of work follow this, the impact on productivity and efficiency can be tremendous and can deter safe conduct. Because of these factors, an absence of sufficient human resource investment was regarded as the source of police dissatisfaction and corruption.

\subsection{Resource shortage}

Certain systemic factors of police corruption exist in Pakistan, besides the aforementioned. The police stations do not have the resources to run their official daily business, as stated previously. Chino states that "the police initiatives are still not funded, with a mere PKR 8,000 (US\$ 120) in the average budget per year for a police station" (Chino, 2001, p. 42). "The funding increase is still not substantial" (Senior officer 4). Latest report (2017-2018) by Police Inspector General Punjab shows that only $12 \%$ of the overall budget for police operations is distributed. The balance is invested on wages and benefits (GoP, 2017-18). Even so, 88 percent of the budget of PKR 1.970 billion, including wages and allowances (\$12.76 million), in Punjab is negligible for a law-maintaining police force of 110.012.442 Punjab citizens. No pay adjustment mechanism was initiated by the government considering such a low budget. Senior officers of the police have said that police stations default in the payment of utility bills on hundreds of thousands of rupees. The police are not kept responsible for the fact that "compulsory forces of the police do not trigger police officers in different utilities to trouble defaults" (Senior official 3). The fuel is regulated by police. In remote regions, though, "police station automobiles supply 6 litres of diesel per day. Fuel for cars is not available at a certain police station whatsoever" (Mid-level officer 6).

According to another mid-level police officer:

"In practice, both in rural and urban areas, it is an unofficial responsibility of police stations to mobilize their resources to bear all operating costs ranging from the investigation of a crime, arranging vehicles and fuel for raids, expenses of forensic tests and serologist, chemical examiners and firearms expert reports to utility bills, and even stationary for office use. Such a practice forces police to mobilize the required resources through unofficial means (Mid-level officer 3).”

Assets are mobilized by payoffs, bribes not being registered in the First Investigative Report, criminal rights being covered, criminal prosecutions compromised, proof being obtained or withheld for and against an accused individual (Criminal Lawyer 1). In addition, police stations are purchased and sold and incentives are issued to senior officials (Criminal Lawyer 1). Such fraudulent acts are evidence of Roebuck and Baker's typology of corruption (1974).

\subsection{Moral economy}

There are also cultural factors of corruption. The African background clarified the 'ethnic embedding of corruption' by the 'social contract' of Olivier de Sardan (1999). Even so, a stagnant, homogenous or deterministic culture theory does not mean a cultural embedding of corruption It refers instead to 'some social standards commonly supported in Africa today, that 'communicate,' or affect corruption practices' (Olivier de Sardan, 1999, p. 2). The concept of redistributive accumulation is embedded in the 'social contract,' that is, the government official who obtains power (small and big) does not only favor his family and moreover operates in a family-oriented society for the support of his/her wider family, his/her associates and the community (Sayed \& Bruce, 1998; Smith, 2010).

Such a "moral economy" factor is important in the Pakistani context of police corruption. Pakistani culture is based on a strong parenthood (Lyon 2004), in which persons do not live as people, although as people. In several situations the financial responsibility of the family and the wider family are the fathers of the family several times. A case in point of a junior police officer is: 
"I have the responsibility to feed my family and my brother's family, which includes my six children and his wife, along with the three children and a wife of my deceased brother. My conscience, as well as the fear of being stigmatized by my extended family for not supporting my late brother's family, forces me to take care of them too. In the absence of adequate salary and social services available to me, I have no choice but to earn money from illegal means. (Junior officer 3)"

The pervasive corruption in the police is due to the essence of the cultural structures, and the economic insecurity of police officers, which also manage their official relations. As a senior police officer pointed out, "bribers often use the common social norms of gift exchange and present costly gifts to government officials to gain compliments" (Senior police officer 6).

It is in accordance with what the officials of the Police department regard as an invalidity system if the officer received certain gifts are appropriate to the department and the corrupting is one of the honorable class of people, Chattha and Ivkovic (2004, p.167) in response to the referendum to Roebuck and Bahrain (1974), which he named "corruption of authority.' This refers to a comprehensive range of corruption, which overlaps the legitimate and cultural definitions of corruption and creates the space for the so called moralizing mechanism of corruption, Olivier de Sardan (1999).

\subsection{Politicization of policing}

South Asia has a strong political impact on the police. In Bangladesh, too, political power leads to police corruption, for example, the Lamani, the Venumadhava (2013, p. 234) observed that 'the transfer and placement of officers was a regular practise in India and was like a rewards and sanctions that led several police officers to be politically alleged' (see Kashem, 2005; Sadiq, 2014). In Afghanistan, bribery, ransom, racial unfairness has been motivated by political leaders aligned with drug smugglers in the police (Singh, 2014).

Political power on police officers' transition and transfer is a strong weapon to regulate the police force. In this background, a policy analyst mentioned:

"It is not considered corruption if a police officer asks a politician4 to get him a posting of his choice. But then such favours come at a price such as favouring the politician in police investigations, posting SHOs of their choice to establish the authority of a politician in his constituency, irrespective of any considerations of efficiency and integrity. Very rarely, an officer gets a good posting without political patronage. The workplace procedures are seldom followed (Policy analyst 6)."

He said that the idea of "successful placements" applies to field tasks where a law enforcement officer plays a major role in the lives and freedoms of people by providing them with advantages of malfunctioning and corruption. Police officials struggle in this sense, whether unable or unwilling to represent politicians. Some other analyst for policy mentioned:

"The police officers with no access to political support mostly end up as Officer on Special Duty (OSD). The post of OSD is considered no less than punishment to officers who do not serve the interests of politicians because they are hardly assigned any work or offices, and are never given field postings (Policy analyst 7)."

The legal side of granting unchecked law enforcement is an appalling trend. A criminal prosecutor identified the following:

"The draconian colonial laws to subvert political uprising are still not only present on paper but are frequently practised in spirit. The legislative aspect of providing police with unbridled legal authority to crush political opposition is a horrific phenomenon (Criminal lawyer 1)."

Section 16 of the notorious Public Order Maintenance (MPO) Act, which requires police imprisonment up to 6 months for those deemed accused of committing peace and security, confirmed this observation. The official position is overridden when an individual is tried in compliance with 16 MPO's, and the home office must be appealed for the revocation of the warrant (see the maintenance of a police order (MPO, 1960). If applied in a district, section 144 of the Code on Criminal Procedure forbs any type of assembly involving a party of four or more persons (MPO, 1960).

It is doubtful that this situation will improve over the day, and in the majority of regions the power of politicians and control of the police will continue as police stations are, as described above, the centre of democratic politics and are used to intimidate politicians in the opposing party, to rig actions and maintain relations between employers and customers. Consequently, there does not appear to be the democratic willingness liberate the police from government pressure and exploitation. It is quite doubtful that the current state of policing operations will improve without the political will of the ruling class.

\section{Conclusion}

The research findings indicate clearly that a detailed account of police corruption in Pakistan can be understood without determining the financial, cultural and political connection between corruption. Key financial reasons have been identified for both individual and institutional corruption. One is low salaries, and another is an inadequate operating budget. In the lack of the possibility of being captured as the principle of public election, low salaries contribute to corruption on an individual level because the police make reasonable decisions. There may also have been some rotten apples hired. The lack of sufficient funds for day-to-day police operations means that police officers are unable to manage their official business without such transactions, justifying the systemic theory of police corruption. The theory of public choice and the systemic theory of police 
corruption were therefore interconnected since it is difficult to have a payoff for personal benefit by creating organizational wealth by fraudulent transactions. In Pakistan it cannot therefore be isolated as an institutional requirement for corruption of the police for personal benefit in mitigating the consequences of low salary for existence, or luxurious life in certain situations at the senior level.

In the above background, Khalid (2016, p. 256), a review of three traffic police departments in three cities, including Islamabad, Rawalpindi and Attock in Pakistan, claims that more funds for paying higher wages are apparently not limited to infringements on honesty. The situation, though, does not appear to be justified since this rise in wages after 5-7 years, as stated in our study results, does not appear sufficient to reduce breaches in the credibility of the police force.

\subsection{Future research directions}

The research findings and analysis will undoubtedly lead to identifying the multidimensional triggers of policing corruption among the police community in Pakistan and South Asia. In addition, whereas the study contributes to Pakistan's literature on police corruption, there is still more to do on the research level. Study inadequacy also hinders attempts; research needs to be supported both by the government and the police. This research concentrated on the reasons for the corruption of the police.

Further studies are important which will probably make more knowledge and research available, various policy options, reform mechanisms and curriculum development programs; increasing community understanding; evolving organizational cultures; providing new technologies for research study and improving the criminal justice system for the police.

\section{References}

Abbas, H. (2011). Reforming Pakistan's Police and Law Enforcement Infrastructure. http://www.usip.org/sites/de fault/files/SR266-Reforming Pakistan\%E2\%80\%98sPoli ceandLawEnforcementInfrastructure.pdf (accessed 24 November 2018).

Ahmed, R., \& Ahmed, Q. M. (2012). Petty corruption in the police department: A case study of Slum Areas of Karachi. Developing Country Studies, 2(6), 78-86.

Australian Code for the Responsible Conduct of Research (2007). https://www.nhmrc.gov.au/about us/publications/aus tralian-code-responsible-conduct-research-2007 (accessed 20 November 2019).

Australian Code for the Responsible Conduct of Research (2018). https://www.nhmrc.gov.au/about us/publications/aus tralian-code-responsible-conduct-research-2018 (accessed 20 November 2019).

Babakhel, A. M. (2018). Police reforms. https://www.dawn. com/news/1410471/police-reforms (assessed 30 March 2019).

Bardhan, P. (1997). Corruption and development: A review of issues. Journal of Economic Literature, 35(3), $1320-1346$.

Buttle, J. W., Graham Davies, S., \& Meliala, A. E. (2016). A cultural constraints theory of police corruption: Understanding the persistence of police corruption in contemporary Indonesia. Australian \& New Zealand Journal of Criminology, 49(3), $437-454$.

Chadwick, B. A., Bahr, H. M., \& Albrecht, S. L. (1984). Social Science Research Methods. New Jersey: Prentice-Hall.

Chattha, Z. N., \& Ivkovic K. S. (2004). Police Misconduct: The Pakistani Paradigm. In Klockars C. B., Ivkovic S. K., and Haberfeld M. R. (eds), The Contours of Police Integrity. London: Sage Publications, pp. 175-190.

Chino, T. (2001). Report and recommendation of the president to the board of directors on proposed loans and technical assistance grant to the Islamic republic of Pakistan for the access to justice program. Manila: Asian Development Bank.

Creswell, J. W. (2013). Qualitative Inquiry and Research Design: Choosing among Five Approaches. Thousand Oaks, CA: SAGE Publications.

Dias, C. F., \& Vaughn, M. S. (2006). Bureaucracy, managerial disorganisation, and administrative breakdown in criminal justice agencies. Journal of Criminal Justice, 34(5), 543-555.

Dogar, A. S. (2017). Corruption remains a systemic problem in Pakistan. https://tribune.com.pk/story/1366745/ corruptionremains-systemic-problem-Pakistan/ (accessed 12 January 2019).

Fluid Survey (2013). Screening questions. http://fluidsur-veys.com/university/screening-questions/ (accessed 12 February 2020).

Fasihuddin (2013). Criminology and the Criminal Justice System in Pakistan. In Liu, J., Bill, H., and Susan, J. (eds), Handbook of Asian Criminology. New York: Springer, pp. 247-281.

Government of the Punjab (2018). Multiple Indicator Cluster Survey 2017-18, Bureau of Statistics. http://bos. gop.pk/MultipleIndicatorClusterSurvey2017 (accessed 12 February 2020).

GoP (2017-18). Punjab Police Budget. AIG Finance, Paki-stan: Government of Punjab.

Graaf, D. G. (2007). Causes of corruption: Towards a contextual theory of corruption. Public Administration Quarterly 31(1/2), 39-86.

Kaufmann, D., \& Vicente, P. C. (2011). Legal corruption. Economics \& Politics, 23(2), 195-219.

Gregory, R. J. (1999). Social capital theory and administrative reform: Maintaining ethical probity in public service. Public Administration Review, 59(1), 63. 
Gupta, A. (1995). Blurred Boundaries: The Discourse of Corruption, the Culture of Politics, and the Imagined State. American Ethnologist, 22(2), 375-402.

Heywood, P. (1997). Political corruption: Problems and perspectives. Political Studies, 45(3), 417-658.

Hurbert, W. (2002). Core factors of police corruption across the world. In Forum on Crime and Society, 2(1), 85-99.

Jackson, J., Asif, M., Bradford, B., \& Zakria Zakar, M. (2014). Corruption and police legitimacy in Lahore Pakistan. British Journal of Criminology, 54(6), 1067-1088.

Jancsics, D. (2014). Interdisciplinary perspectives on corruption. Sociology Compass, 8(4), 358-372.

Khan, M. T., Khan, N. A., Ahmed, S., \& Mehmood, K. (2012). Corruption: Causes and effects in Pakistan's case (A review research). International Journal of Business and Behavioral Sciences, 6, 79-91.

Kashem, M. B. (2005). The Social Organisation of Police Corruption: The Case of Bangladesh. In Sarre, R., Das, D. K., Albrecht, H. J. (eds), Policing Corruption: International Perspectives. Lanham, MD: Lexington Books, pp. $237-246$.

Khalid, S. U. (2016). Theory and practice of police corruption in Pakistan: Case Studies of Three Police Departments. Ph.D. dissertation, University of Amsterdam.

Khan, M. (2006). Determinants of Corruption in Developing Countries: The Limits of Conventional Economic Analysis. In Rose-Ackerman (ed) International Handbook on the Economics of Corruption. Cheltenham: Edward Elgar, pp. $216-244$.

Kleinig, J. (1996). The Ethics of Policing. Cambridge University Press.

Klitgaard, R. (1988). Controlling Corruption. Berkeley: University of California Press.

Klockars, C. B. (1999). Police corruption in thirty agencies in the United States, 1997 [Computer file]. http://www.icpsr.umich.edu (accessed 24 November 2018).

Lamani, R. B., \& Venumadhava, G. S. (2013). Police corruption in India. International Journal of Criminology and Sociological Theory, 6(4), 228-234.

Lee, H., Lim, H., Moore, D. D., \& Kim, J. (2013). How police organisational structure correlates with frontline officers' attitudes toward corruption: A multilevel model. Police Practice and Research, 14(5), 386-401.

Lyon, S. M. (2004). An Anthropological Analysis of Local Politics and Patronage in a Pakistani Village. New York: Edwin Mellen Press.

Madichie, N. O. (2005). Corruption in Nigeria: How effective is the corruption perception index in highlighting the economic Malaise? World Review of Science Technology and Sustainable Development, 2(3/4), 320-335.

Maintenance of Police Order (MPO) (1960). West Pakistan Maintenance of Public Order Ordinance. https: //www.malaw.org.pk (accessed 20 June 2019).

Naderifar, M., Goli, H., \& Ghaljaie, F. (2017). Snowball sampling: A purposeful method of sampling in qualitative research. SDMEJ, 14(3), 1-6.

Newburn, T. (1999). Understanding and Preventing Police Corruption: Lessons from the Literature. London: Home Office.

Noon, E. J. (2018). Interpretive Phenomenological Ana-lysis: An Appropriate Methodology for Educational Research?. Journal of Perspectives in Applied Academic Practice, 6(1), 75-83.

North, D. C., Wallis, J. J., \& Weingast, B. R. (2009). Violence and Social Orders: A Conceptual Framework for Interpreting Recorded Human History. New York: Cambridge University Press.

NAB (2002). National Anti-Corruption Strategy (NACS). National Accountability Bureau, Islambad: Government of Pakistan.

Paul. J., \& Du, J. (2018), Effects of minimum wages on population health: https://www.healthaffairs.org/do/10. 1377/hpb20180622.107025/full/ (accessed 8 February 2020).

Olivier de Sardan, J. P. (1999). A moral economy of corruption in Africa? Journal of Modern African Studies, 37(1), $25-52$.

Porter, L. E., \& Warrender, C. (2009). A multivariate model of police deviance: Examining the nature of corruption, crime and misconduct. Policing and Society, 19(1), 79-99.

Punch, M. (1985). Conduct Unbecoming: The Social Construction of Police Deviance and Control. London: Tavi-stock, p. 136.

Punch, M. (2009). Police Corruption: Deviance, Accountability and Reform in Policing. Routledge.

Punch, M. (2000). Police corruption and its prevention. European Journal on Criminal Policy and Research, 8(3), $301-324$.

Quah, J. S. (2006). Preventing police corruption in Singapore: The role of recruitment, training and socialisation. Asia Pacific Journal of Public Administration, 28(1), 59-75.

Quah, J. S. (2010). Defying Institutional Failure: learning from the Experiences of anti-Corruption Agencies in Four Asian Countries. Crime, Law and Social Change, 53(1), 23-54.

Raza, H., Iraqi, K. M., Zaidi, S. S. Z., \& Raza, A., (2015). The law and order situation and its impact on foreign direct investment in Pakistan. International Journal of Management Sciences, 5(11), 736-746.

Reynolds, P. D., Fitzgerald, B. A., \& Hicks, J. (2018). The expendables: A qualitative study of police officers responses to organisational injustice. Police Quarterly, 21(1), 3-29.

Rijckeghem, V. C., \& Weder, B. (2001). Bureaucratic corruption and the rate of temptation: Do wages in the civil service affect corruption, and by how much?. Journal of Development Economics, 65(2), 307-331.

Rose-Ackerman, S. (1999). Corruption and Government: Causes, Consequences, and Reform. Cambridge: Cambridge University Press.

Rose-Ackerman, S. (1996). Democracy and Grand Corruption. International Social Science Journal, 48(149), $365-380$.

Roebuck, J. B., \& Barker, T. (1974). A typology of police corruption. Social Problems, 21(3), 423-437. 
Sadiq, E. (2014). Quest for democratic policing politics of po-lice reforms in Pakistan. http://www.rozan.org/sites/de fault/files/Quest $\% 20$ for $\% 20$ Democratic\%20Policing\%20by $\% 20 \mathrm{DIG} \% 20 \mathrm{Dr} \% 20$ Ehsan $\% 20$ Sadiq $\% 20$ from $\% 20 \mathrm{Rozan}$ $\% 20 \% 28$ final\%29.pdf (accessed 14 March 2019).

Sajid (2016). Rs 852 billion corruption in public sector entities exposed. https://dailytimes.com.pk/53647/rs-852-billion-corruption-in-public-sector-entities-exposed (accessed 28 March 2019).

Sayed, T., \& Bruce, D. (1998). Police corruption: Towards a working definition. African Security Review, 7(1), 3-14.

Shore, C., \& Haller, D. (eds) (2005). Corruption: Anthropological Perspectives. London: Pluto Press.

Sherman, L. W. (1978). Scandal and Reform: Controlling Police Corruption. Berkeley, CA: University of California Press.

Singh, D. (2014). Corruption and clientelism in the lower levels of the Afghan police. Conflict, Security \& Development 14(5), $621-650$.

Singh, D. (2015). Explaining varieties of corruption in the Afghan justice sector. Journal of Intervention and State building, 9(2), 231-255.

Singh, D. (2019). Understanding corruption in the lower levels of the Afghan police force. The Police Journal, 1-31. doi: $10.1177 / 0032258 X 19862014$.

Sissener, T. K. (2001). Anthropological Perspectives on Corruption. Norway: Bergen.

Smith, D. J. (2010). A Culture of Corruption: Everyday Deception and Popular Discontent in Nigeria. Princeton, NJ: Princeton University Press.

Tankebe, J. (2010). Public confidence in the Police: Testing the effects of public experiences of Police corruption in Ghana. British Journal of Criminology, 50(2), 296-319.

Transparency International (TI) (2013). Corruption risks in Pakistan. https:/www.transparency.org/files/content/feature/2014_CorruptionSouthAsia_factsheet_Pakistan. pdf (accessed 10 February 2019).

Transparency International (TI) (2019). Corruption per-ceptions index 2019. https://www.transparency.org/new s/feature/corruption_perceptions_index_2019 (accessed 10 February 2019).

The News (2019). Only one percent Pakistanis pay taxes: FBR. https://www.thenews.com.pk/print/425729-only-one-percentpakistanis-pay-taxes-fbr (accessed 20 February 2019).

TransferWise (2017). Cost of Living in Pakistan: Your Guide. https://transferwise.com/gb/blog/cost-of-livin-g-in-pakistan (accessed 12 Feburary 2020).

Uberti, L. J. (2016). Can Institutional Reforms Reduce Corruption? Economic Theory and Patron-Client Politics in Developing Countries. Development and Change, 47(2), 317-345.

UNDP (2016). Pakistan's new poverty index reveals that 4 out of 10 Pakistanis live in multidimensional poverty. http://www.pk.undp.org/content/pakistan/en/home/press center/pressreleases/2016/06/20/pakistan-s-new-poverty-indexreveals-that-4-out-of-10-pakistanis-live-in-multidi mensional-poverty.html (accessed 14 March 2019).

Verma, A. (1999). Cultural roots of Police corruption in India. Policing: An International Journal of Police Strategies \& Management, 22(3), 264-279.

Waddington, P. A. J. (1999). Police (Canteen) sub-culture: An appreciation. British Journal of Criminology, 39(2), $287-309$.

Zakiuddin, A., \& Haque, W. (1998). Corruption in Bangladesh: an analytical and sociological study. https:// pdfs.semanticscholar.org/c1e4/f6eeb161bf5ace8facb607aa 53dc0cd48c3c.pdf (accessed 18 March 2019).

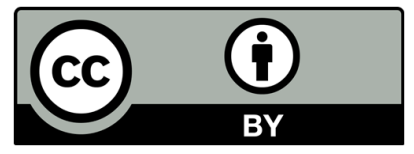

(C) 2021 by the authors; licensee Growing Science, Canada. This is an open access article distributed under the terms and conditions of the Creative Commons Attribution (CC-BY) license (http://creativecommons.org/licenses/by/4.0/). 